\title{
Pengaruh Pendidikan Dan Kesehatan Terhadap Pertumbuhan Ekonomi Di Kabupaten Teluk Bintuni Periode 2010-2018
}

\author{
Dody Akbar ${ }^{1}$, Sarce B. Awom², Siti Aisah Bauw ${ }^{3}$ \\ ${ }^{1}$ Alumni Jurusan Ekonomi Pembangunan, Universitas Papua \\ 2,3 Dosen Jurusan Ekonomi Pembangunan, Universitas Papua
}

\begin{abstract}
Abstrak
Penelitian ini bertujuan untuk mengetahui Pengaruh Pendidikan Dan Kesehatan Terhadap Pertumbuhan Ekonomi Di Kabupaten Teluk Bintuni Periode 2010-2018 Jenis penelitian ini adalah penelitian kuantitatif. Penelitian ini menggunakan data Panel time series dan teknik pengumpulan data Sekunder. Analisis data menggunakan Uji Keofisien Determinasi Uji Heteroskedasitas Uji f Uji t. Hasil penelitian ini menunjukkan (X1) Pendidikan Dan (X2) Kesehatan berpengaruh positif dan signifikan terhadap (Y) Pertumbuhan Ekonomi.
\end{abstract}

Kata Kunci: Pertumbuhan Ekonomi, Pendidikan, Kesehatan.

\begin{abstract}
This study aims to determine the effect of education and health on economic growth in Teluk Bintuni Regency for the 2010-2018 period. This type of research is quantitative research. This research uses time series data and secondary data collection techniques. Analysis of the data using the Coefficient of Determination Test Heteroscedasticity Test $f$ Test $t$ test. The results of this study show (X1) Education and (X2) Health have a positive and significant effect on (Y) Economic Growth.
\end{abstract}

Keywords: Economic Growth, Education, Health

How to Cite: Akbar, D., Awom, Sarce B., \& Bauw, Siti A. (2021). Pengaruh Pendidikan Dan Kesehatan Terhadap Pertumbuhan Ekonomi Di Kabupaten Teluk Bintuni Periode 2010-2018. JFRES: Journal of Fiscal and Regional Economy Studies, 4(1), 8 - 14 


\section{PENDAHULUAN}

Pembangunan merupakan proses multidimensi yang mencangkup perubahan-perubahan penting dalam struktur sosial, sikap-sikap rakyat dan lembanga-lembanga nasional serta akselerasi pertumbuhan ekonomi, pengurangan kesenjangan, dan pemberantasan kemiskinan absolute pembangunan sebagai suatu proses belajar (Todaro dan Smith, 2006).

Pembangunan perlu dilakukan secara terpadu agar memberikan pengaruh yang lebih luas, sebagaimana (Wanga et al, 2018) menyimpulkan bahwa pengelolaan lahan terpadu dapat menciptakan lahan pertanian, melestarikan tanah dan air, memperkuat konstruksi infrastruktur pertanian, mendorong pertanian skala besar dan mempramosikan pembangunan ekonomi pedesaan. Secara nasional, terjadi ketimpangan wilayah dalam sumber daya, pendapatan, demografis pengangguran dan kesempatan kerja, pertumbuhan daerah, migrasi, tingkat perbedaan permintaan, perubahan struktur sosial, polarisasi dan lain sebagainya (Nurhadi, 2012).

Pendidikan sangat berperan penting dalam pembangunan baik itu dalam pembangunan sumber daya manusia, ekonomi, sosial dan bahkan masih lebih banyak lagi peranan pendidikan dalam pembangunan masyarakat, bangsa dan Negara. Namun hal tersebut tidak diikuti dengan peningkatan kualitas pendidikan yang sepadan dengan anggaran yang telah dikeluarkan.Hal ini terbukti dengan banyaknya pengganguran akademik di Indonesia yaitu sebesar 4,1 juta orang (Kompas, 2010).

Ketimpangan pengembangan SDM di Indonesia menggambarkan adanya kesenjangan kualitas pendidikan yang cukup besar antara satu daerah dengan daerah lainnya, antara kota dan desa, pembangunan pendidikan dari yang paling dasar sampai dengan tingkat atas sangat terasa. Hal ini dibuktikan dengan kurangnnya fasilitas pendidikan maupun guru yang mengajar di desa yang mengakibatkan tingginya angka buta huruf dan kadar penggunaan bahasa Indonesia yang masih rendah di pedesaan maupun daerah pelosok, maka sangat perlu untuk memperhatikan sarana prasaranan pelayanan pendidikan. Hasil penelitian yang dilakukan oleh Priraharjo (2007), bahwa salah satu penyebab rendahnya efektifitas pendidikan di Indonesia adalah tidak adanya tujuan pendidikan yang jelas sebelum kegiatan pembelajaran dilaksanakan. Hal ini menyebabkan peserta didik dan pendidik tidak tahu apa yang dihasilkan sehingga tidak mempunyai gambaran jelas dalam proses pendidikan.

Mahalnya biaya pendidikan membuat banyak generasi muda Indonesia yang tidak bersekolah karena keterbatasan biaya bahkan yang berprestasi tidak mampu melanjutkan prestasinya. Pendidikan merupakan suatu proses pemberdayaan untuk mengungkapkan potensi yang ada pada manusia sebagai individu, yang selanjutnya dapat memberikan sumbangan kepada masyarakat lokal, kepada masyarakat bangsannya, dan kemudian kepada masyarakat global. Dengan demikian, fungsi pendidikan bukan hanya mengenai potensi-potensi yang ada di dalam diri manusia, tetapi juga bagaimana manusia ini dapat mengontrol potensi yang ada yang telah dikembangkan itu agar dapat bermanfaat bagi peningkatkan kualitas hidup manusia itu sendiri.

Dari sisi konsumen manusia ditempatkan sebagai pemanfaat akhir dari hasil pembangunan, dan dari sisi produsen sebagai faktor input yang penting dalam proses produksi. Proses pendidikan menjadi bagian yang tidak terpisahkan atau bagian intergral dari pengenbangan SDM sebagai subjek sekaligus objek pembangunan. Pendidikan harus mampu melahirkan SDM yang berkualitas dan bukan menjadi beban pembangunan dan masyarakat, yaitu SDM yang menjadi sumber kekuatan atau sumber penggerak (driving forces) bagi seluruh proses pembangunan dan kehidupan masyarakat. Untuk itu, pendidkan semestinya berhubungan secara timbal balik dengan pembangunan di berbagai bidang (politik, sosial, ekonomi, budaya). Sehingga pendidikan akan dapat dimaknai sebagai suatu bentuk investasi SDM untuk menciptakan iklim yang memungkinkan semua penduduk atau warga negara yang produktif.

Dari tujuan tersebut tercermin bahwa sebagai titik sentral pembangunan adalah pemberdayaan sumber daya manusia, baik sebagai sasaran pembanguan maupun sebagai pelaku pembangunan. Dengan demikian, pembangunan pendidikan merupakan salah satu aspek 
pendudkung keberhasilan pembangunan nasioanal.

Pendidikan merupakan salah satu bentuk investasi utama dalam meningkatkan kualitas sumber daya manusia. Artinya, setiap pengeluaran yang dipergunakan untuk pendidikan dianggap sebagai pengeluaran yang hasilnya bukan untuk dinikmati sekarang tetapi pada masa yang akan datang. Sebagai investasi, pembangunan pendidikan sudah selayaknya mendapatkan porsi anggaran yang signifikan dalam rangka meningkatkan kualitas SDM penduduk Indonesia sesuai dengan potensi alam sekitar agar dapat menghasilkan produk dan jasa layanan yang sangat besar dan tersebar ini dapat dipetakan dan kemudian strategi dan kebijakan pendidikan yang memperhatikan aspek-aspek penting pendidikan, baik ekonomi, politik, sosial, dan budaya bangsa Indonesia sehingga peringkat HDI Indonesia dapat terus meningkat ke arah yang lebih baik.

Kesehatan merupakan salah satu kebutuhan dasar masyarakat, oleh karena itu kesehatan adalah hak bagi setiap warga masyarakat yang dilindungi Undang- Undang Dasar. Perbaikan pelayanan kesehatan pada dasarnya merupakan suatu investasi sumberdaya manusia untuk mencapai masyarakat yang sejahtera (welfaresociety). Tingkat kesehatan masyarakat akan sangat berpengaruh terhadap tingkat kesejahteraan masyarakat, karena tingkat kesehatan memiliki keterkaitan yang erat dengan kemiskinan. Sementara itu, tingkat kemiskinan akan terkait dengan tingkat kesejahteraan. Oleh karena itu kesehatan merupakan faktor utama kesejahteraan masyarakat yang hendak diwujudkan pemerintah, maka kesehatan harus menjadi perhatian utama pemerintah sebagai penyelenggara pelayanan publik. Pemerintah harus dapat menjamin hak masyarakat untuk sehat (rightforhealth) dengan memberikan pelayanan kesehatan secara adil, merata, memadai, terjangkau, dan berkualitas. Indikator kesehatan meliputi keshatan balita dan kesahatan ibu melahirkan, ibu menyusui, laki-lakiperempuan dewasa serta lansia yang harus diperhatikan oleh Negara yang sebagai lembaga penjamin kesehatan masyarakat Indonesia dengan memberikan kemudahan-kemudahan melalui kartu jaminan kesehatan baik, pemerintah, swasta dan wiraswasta melalui kartu jamsostek, BPJS, ASKES, JAMKESMAS dan Kartu Indonesia sehat (KIS).
Sejak tahun 2001 Papua menjadi salah satu daerah yang diberikan Otonomi khusus dan mulai menerapkan UU No. 22 Tahun 1999 yang kemudian diganti dengan UU No. 32 Tahun 2004 dan diganti dengan UU No. 12 Tahun 2008 tentang Pemerintahan Daerah yang dikenal sebagai Undang-Undang Otonomi Daerah. Dalam penerapannya, undang-undang tersebut diiringi dengan pemberlakuan UU No. 25 Tahun 1999 tentang perimbangan keuangan antara Pemerintah Pusat dan Daerah dan diganti dengan UU No. 33 Tahun 2004. Yaitu daerah diberikan kewenangan oleh negara untuk mengatur dan mengelolah daerah serta keuangannya sendiri atau disebut sistem desentralisasi. Dengan kewenangan tersebut berbabagai upaya yang dilakukan oleh pemerintah daerah, untuk meningkatkan pembangunan dari berbagai aspek, Sosial, Ekonomi dan Budaya.

Kondisi perekonomian di Kabupaten Teluk Bintuni terus mengalami pertumbuhan yang terus naik meskipun lambat sebagaimana tergambar dalam ekonomi pada tabel 1 menujukkan bahwa pertumbuhan Ekonomi terus meningkat setiap tahun, adanya peningkatan dalam pertumbuhan ekonomi di Kabupaten Teluk Bintuni ditunjukkan dengan adanya peningkatan pertumbuhan dari setiap sektor maupun sub sektor ekonomi secara signifikan, terutama sektor Pertanian, Kehutanan dan Perikanan, Sektor Pertambangan dan Penggalian dan sektor Indusstri Pengolahan.

Tabel 1. Pertumbuhan Ekonomi Kabupaten Teluk Bintuni Tahun 2010-2018

\begin{tabular}{cc}
\hline Tahun & Pertumbuhan Ekonomi $(\boldsymbol{\%})$ \\
\hline 2010 & 56,99 \\
\hline 2011 & 57,87 \\
\hline 2012 & 58,48 \\
\hline 2013 & 59,73 \\
\hline 2014 & 60,40 \\
\hline 2015 & 61,09 \\
\hline 2016 & 61,81 \\
\hline 2017 & 62,39 \\
\hline 2018 & 63,13
\end{tabular}

Sumber: BPS Kabupaten Teluk Bintuni, 2020

Kabupaten Teluk Bintuni mulai berkembang dari tahun-tahun sebelumnya ini dapat dilihat dimana jumlah sekolah dasar, sekolah menengah dan sekolah menegah atas yang mulai bertambah dari tahun sebelumnya, peningkatan sarana dan prasaranan dalam menunjang pendidikan dan juga penambahan jumlah guru pengajar. Kemudian kondisi kesehatan di 
Kabupaten Teluk Bintuni bisa dikatakan cukup memadai baik dalam fasilitas kesehatan rumah sakit maupun tenaga medis dalam menangani pasien.

Teori pengeluaran pemerintah menurut (Sukirno, 2000). Dalam rangka mencapai kondisi masyarakat yang sejahtera, pemerintah menjalankan berbagai macam program pembangunan ekonomi. Aktivitas pemerintah dalam melakukan pembangunan membutuhkan dana yang cukup besar, pengeluaran pemerintah menceriminkan kombinasi produk yang dihasilkan untuk menyediakan barang pubik dan pelayanan kepada masyarakat yang memuat pilihan atau keputusan yang dibuat oleh pemerintah. Teori pengeluaran pemerintah adalah identitas keseimbangan pendapatan nasional dimana merupakan campur tangan pemerintah dalam perekonomian (Dumairy, 1996).

Pertumbuan Ekonomi adalah suatu proses perubahan perekonomian suatu negarah berkelanjutan menuju kaadaan yang lebih baik selama periode tertentu. Pertumbuan ekonomi juga dapat diartikan sebagai proses terjadinya kenaikan produk nasional bruto atau pendapatan national rill. Sedangkan pertumbuhan ekonomi menurut (Sukirno, 2000).

Pada umunnya membangunan ekonomi diartikan sebagai rangkaian usaha dalam suatu perekonomian untuk mengembangkan ekonominya sehingga infrastrukturr lebih banyak tersedia, perusahan semakin banyak dan semakin berkembang, tarak pendidikan semakin tinggi dan teknologi semakin meningkat. Pembangunan ekonomi adalah pertumbuhan ekonomi di tambah dengan perubahan. Artinya dari pernyataan tersebut adalah pembangunan ekonimi dalam suaru negarah pada suatu tahun tertentu tidak hanya di ukur dari produksi barang dan jasa yang berlaku dalam kegiatan ekonomi seperti perkembangan pendidikan, perkembangan teknologi, peningkatan dalam kesehatan, peningkatan infrastuktur yang tersedia dan peningkatan dalam pendapatan dan kemakmuran masyarakat.

Suatu Negara yang memberikan perhatian lebih kepada pendidikan terhadap masyarakatnya ceteris paribus akan menghasilkan pertumbuhan ekonomi yang lebih baik dari pada tidak melakukannya. Dengan kata lain, investasi terhadap sumberdaya manusia melalui kemajuan pendidikan akan menghasilkan pendidikan akan menghasilkan pendapatan nasional atau pertumbuhan ekonomi yang lebih tinggi. Apabila investasi tersebut dilakukan secara relatife merata, termasuk terhadap gologan berpendapatan rendah, maka kemiskinan akan berkurang (Mankiw, 2004).

Pertumbuhan ekonomi diyakini oleh sebagian besar ekonom sebagai indikator yang paling tepat dalam menggambarkan proses kemajuan pembangunan suatu negara. Hal ini terkait dengan kemampuannya dalam mengambarkan proses peningkatan kesejahteraan masyarakat melalui peningkatan kapasitas produksi nasional, peningkatan jumlah konsumsi dan yang terpenting adalah peningkatan pendapatan. Namun, pada kenyataannya pertumbuhan ekonomi hanya mengambarkan nilai secara agregat, bukan secara parsial. Faktanya, proses pertumbuhan ekonomi yang terjadi di dunia pada saat ini memperlihatkan bahwa perumbuhan ekonomi yang tinggi tidak selalu di barengi dengan pembagian porsi pendapatan yang merata diantara para pelaku ekonomi (Arsyad, 2010).

Dalam upaya untuk mencerdaskan kehidupan bangsa diperlukan sebuah perjuangan dan usaha melalui kegiatan pendidikan. Pasal 31 UUD 1945 juga telah jelas mengaturnya bahwa setiap warga negara berhak mendapatkan pengajaran. Selain itu lebih khusus dalam UU No. 20 tahun 2003 tentang Sistem Pendidikan Nasional (Sisdiknas) Bab IV Bagian 1 pasal 5 ayat (1) yang menyatakan bahwa setiap warga negara berhak mendapat kesempatan meningkatkan pendidikan sepanjang hayat.

Kedua ayat ini secara jelas memberikan kesempatan yang sama kepada semua pihak untuk mendapatkan pendidikan yang seluasluasnya. Banyak cara yang telah dilakukan pemerintah dalam upaya memajukan dunia pendidikan di Indonesia. Diantaranya adalah dengan menyelenggarakan program wajib belajar 9 tahun. Maksud dan tujuan pelaksanaan wajib belajar adalah memberikan pelayanan kepada masyarakat untuk memasuki sekolah dengan biaya murah dan terjangkau oleh kemampuan masyarakat. Selanjutnya dalam UU Sisdiknas 2003 pasal 6 disebutkan bahwa setiap warga negara yang berusia tujuh sampai dengan lima belas tahun wajib mengikuti pendidikan dasar. Pendidikan merupakan suatu proses pemberdayaan untuk mengungkapkan potensi yang ada pada manusia sebagai individu, yang 
selanjutnya dapat memberikan sumbangan kepada masyarakat

Pendidikan dasar adalah pendidikan yang berbentuk Sekolah Dasar (SD), dan Madrasah Ibtidaiyah (MI) atau bentuk lain yang sederajat serta Sekolah Menengah Pertama (SMP) dan Madrasah Tsanawiyah (MTs), atau bentuk lain yang sederajat (pasal 17 UU Sisdiknas 2003). Upaya mempercepat tercapainya gerakan pendidikan wajib belajar sembilan tahun terus dilakukan. Pada tahun 2006 pemerintah mengeluarkan Instruksi Presiden RI Nomor Tahun 2006 tentang Gerakan Nasional Percepatan Penuntasan Wajib Belajar Pendidikan Dasar Sembilan Tahun dan Pemberantasan Buta Aksara (PWPPBA). Berbagai lini institusi terkait dilibatkan dalam upaya gerakan pendidikan dasar sembilan tahun dan pemberantasan buta aksara.

Salah satu indikator yang dapat dijadikan ukuran kesejahteraan sosial yang merata adalah dengan melihat tinggi rendahnya presentase penduduk yang melek huruf. Tingkat melek huruf dapat dijadikan ukuran kemajuan suatu bangsa. Angka Melek Huruf (AMH) adalah jumlah penduduk usia 15 tahun ke atas yang dapat membaca dan menulis dengan jumlah penduduk usia 15 tahun ke atas. Batas maksimum untuk angka melek huruf, adalah 100 sedangkan batas minimum 0 (standar UNDP). Hal ini mengambarkan kondisi 100 persen atau semua mampu membaca dan menulis, dan ini nol menunjukkan kondisi sebaliknya.

Mewujudkan pembangunan manusia di bidang kesehatan, diwujudkan melalui penyediaan fasilitas dan tenaga kesehatan yang memadai. Oleh karena itu, penyediaan fasilitas kesehatan dan tenaga kesehatan menjadi sebuah indikator yang layak untuk diperhatikan. Disamping itu, indikator lainnya yang dapat digunakan sebagai tolok ukur pembangunan manusia dalam bidang kesehatan adalah manusia sebagai objek pembangunan itu sendiri. Tingkat kesehatan seseorang dapat dilihat dari sejarah kesehatan yang diruntut dari kondisi kesehatannya sejak lahir, balita, anak-anak hingga dewasa. Sedangkan tingkat kesehatan pada masyarakat secara umum dapat dilihat dari tingkat pesakitan atau jumlah keluhan kesehatan, tingkat kematian bayi, penolong kelahiran bayi, dan lain-lain

Perhatian pemerintah dalam membangun indeks pembangunan manusia di bidang kesehatan, diwujudkan melalui penyedian fasilitas dan tenaga kesehatan yang memadai. Oleh karena itu, penyediaan fasilitas kesehatan dan tenaga kesehatan menjadi sebuah indikator yang layak untuk diperhatikan. Disamping itu, indikator lainnya yang dapat digunakan sebagai tolok ukur pembangunan manusia dalam bidang kesehatan adalah manusia sebagai objek pembangunan itu sendiri. Tingkat kesehatan seseorang dapat dilihat dari sejarah kesehatan yang diruntut dari kondisi kesehatannya sejak lahir, balita, anak-anak hingga dewasa. Sedangkan tingkat kesehatan pada masyarakat secara umum dapat dilihat dari tingkat pesakitan atau jumlah keluhan kesehatan, tingkat kematian bayi, penolong kelahiran bayi, dan lain-lain.

Angka Harapan Hidup (AHH) merupakan alat untuk mengevaluasi kinerja pemerintah dalam meningkatkan kesejatrahaan penduduk pada umunya, dan meningkakan derajat kesehatan pada kuhsusnya. Angka Harapan Hidup menggambarkan umur rata-rata yang di capai seseorang dalam situasi mortalitas yang berlaku di lingkungan masyarakatnya. Untuk Angka Harapan Hidup yang rendah di suatu daerah menunjukkan pembangunan kesehatan belum berhasil, dan semakin tinggi AHH semakin menunjukkan keberhasilan pembangunan kesehatan di daerah tersebut.

Pendidikan dan kesehatan merupakan tujuan dari pembangunan yang mendasar. Kesehatan merupakan kesejahteraan dan pendidikan merupakan hal yang pokok untuk menggapai kehidupan yang memuaskan dan berharga. Keduanya merupakan hal yang penting untuk membentuk kapabilitas manusia yang lebih luas yang berada pada inti makna pembangunan (Todaro \& Smith, 2006).

\section{METODE PENELITIAN}

Penelitian ini dilaksanakan di Kabupaten Teluk Bintuni Provinsi Papua Barat, menggunakan data sekunder dari Badan Pusat Stastistik Kabupaten Teluk Bintuni dan Badan Pusat Stastistik Provinsi Papua Barat, merupakan data time series (2009-2019). Teknik analisis data yang digunakan dalam penelitian ini adalah teknik analisis secara deksriptif dan kuantitatif dengan regresi berganda yang bertujuan untuk menjelaskan tingkat pendidikan (X1) dan tingkat Kesehatan (X2) sebagai variabel independen terhadap variabel dependen Pertumbuhan ekonomi (Y) di Kabupaten Teluk 
Bintuni tahun 2009-2019. Bentuk Persamaan Model dalam penelitian sebagai berikut:

$$
\begin{aligned}
& \mathrm{Y}=\alpha+\beta 1 \times 1+\beta 2 \times 2+\mathrm{e} \\
& \text { Dimana: } \\
& \alpha \quad=\text { Parameter } \\
& \beta \quad=\text { Konstanta } \\
& \mathrm{X} 1 \quad=\text { Pendidikan } \\
& \mathrm{X} 2=\text { Kesehatan } \\
& \mathrm{Y} \quad=\text { Pertumbuhan ekonomi } \\
& \mathrm{e} \quad=\text { Standar error (Derajat kebebasan 5\%) }
\end{aligned}
$$

\section{HASIL DAN PEMBAHASAN}

\section{Hasil Analisis}

Berdasarkan uji regresi liniear berganda yang telah dilakukan, diperoleh hasil model estimasi regresi liniear berganda dengan persamaan sebagai berikut:

$Y=(-11,333)+3,468+0,788$

1. Ketika Varibel $X_{1}$ dan $X_{2}$ adalah ( 0 ) atau konstan atau tetap maka nilai varibel $\mathrm{Y}$ adalah $(-11,333)$

2. Ketika Variabel $X_{1}$ naik atau bertambah sebesar $1 \%$ dan $\mathrm{X}_{2}$ ceteris Paribus maka akan mempengaruhi variabel Y naik sebesar 3,468 atau $(3,5 \%)$ begitupun sebaliknya Variabel $\mathrm{X}_{1}$ turun atau berkurang sebesar $1 \%$ maka akan mempengaruhi variabel $\mathrm{Y}$ akan turun sebesar 3,468 atau $(3,5 \%)$

3. Ketika Variabel Nilai Veriabel $X_{2}$ naik atau bertambah sebesar $1 \%$ dan $X_{1}$ Ceteris Paribus akan mempengaruhi variabel $\mathrm{Y}$ dan naik sebesar 0,788 atau $(7,8 \%)$ begitupun sebaliknya jika Variabel $\mathrm{X}_{1}$ turun atau berkurang sebesar $1 \%$ maka akan mempengaruhi variabel $\mathrm{Y}$ akan turun sebesa 0.788 atau $(0.8 \%)$

\section{Pembahasan}

Dari hasil analisis yang telah dilakukan, Tingkat Pendidikan dan Tingkat Kesehatan berpengaruh secara signifikan terhadap Pertumbuhan Ekonomi Kabupaten Teluk Bintuni, Hal tergambar secara jelas dalam hasil pengujian statistik yang telah dilakukan baik secara parsil (Uji t statistik) dan secara Simultan (Uji F statistik).

Pengujian Secara Parsial menunjukan Bahwa nilai $\mathrm{t}$ statistik (Nilai $\mathrm{t}$ hitung variabel $\mathrm{X} 1$ (Pendidikan) 6.677 lebih besar ( $>$ ) dari $\mathrm{T}$ tabel 1.761 dan nilai signifikansi 0,001 lebih kecil $(<)$ dari Nilai Probabilitas 0.05 dan Nilai t hitung variabel X2 (Pendidikan) 4.199 lebih besar (>) dari $\mathrm{T}$ tabel 1.761 dan nilai signifikansi 0,006 lebih kecil $(<)$ dari Nilai probabilitas 0.05. Sehingga ketika Terjadi Perubahan pada nilai fluktuasi tingkat Pendidikan dan tingkat Kesehatan Naik atau turun secara signifikan mempengaruhi tingkat Pertumbuhan Ekonomi Di Kabupaten Teluk Bintuni, Hal ini Senada dengan Penelian 1).Muda, dkk., 2018 tentang Pengaruh angka harapan hidup, Tingkat pendidikan dan Pengeluaran perkapita terhadap pertumbuhan ekonomi di Sulawesi utara pada tahun 2013-2017 dan 2). Dewi dan Sutrisna, 2014 tentang Pengaruh komponen Indeks pembangunan Manusia terhadap pertumbuhan ekonomi Provinsi Bali.

Berdasarkan teori Todaro, pertumbuhan ekonomi bisa bersumber dari pertumbuhan pada sisi permintaan agregat terdiri atas tiga komponen yaitu konsumsi rumah tangga, investasi dan pengeluaran pemerintah (Todaro, 2011). Dengan demikian, kontribusi terbesar bagi pertumbuhan ekonomi kabupaten teluk bintuni, berasal dari Investasi yaitu dari Sektor Industri Pengolahan. Kontribusi Sektor Industri Pengolahan menjadi sektor primadona sejak beroperasinya perusahaan besar yaitu Perusahaan LNG Tangguh (Perusahaan Gas BP) yang memacu pertumbuhan ekonomi yang terus bertumbuh pada berbagai sektor.

Analisis Secara deskriptif menunjukkan bahwa pertumbuhan ekonomi, pendidikan dan kesehatan sangat berhubungan erat dimana pendidikan dan kesehatan baik di kabupaten teluk bintuni maka aktivitas ekonomi akan berjalan lancar, masyarakat yang bekerja dengan kemampuan rata-rata diatas standar yang ditentukan oleh karena pendidikan yang memadai sehingga dapat direkrut ke perusahanperusahan besar, dan selanjutnya kesehatan masyarakat yang sehat akan dapat menyelesaikan segala pekerjaannya dan menambah produksinya sehingga dari kedua komponen diatas yang sudah diuraikan akan mendorong dan meningkatkan pertumbuhan ekonomi melalui PDRB per-kapita dan PDRB Harga Konstan, di Kabupaten Teluk Bintuni. Pertumbuhan ekonomi dari tahun 2010-2018 mengalami peningkatan. Sama halnya untuk pendidikan dan kesehatan di Kabupaten Teluk Bintuni dari tahun 2010-2018 terus mengalami peningkatan yang cukup signifikan. 


\section{KESIMPULAN}

Dari hasil penelitian ini dapat disimpulkan bahwa tingkat pendidikan dan tingkat kesehatan berpengaruh secara signifikan terhadap pertumbuhan Ekonomi Kabupaten Teluk Bintuni. Hal ini tergambar secara jelas dalam hasil pengujian statistik yang telah dilakukan baik secara parsil (Uji t statistik) dan secara Simultan (Uji F statistik).

Pengujian Secara Parsial menunjukan Bahwa nilai $\mathrm{t}$ statistik (Nilai $\mathrm{t}$ hitung variabel $\mathrm{X} 1$ (Pendidikan) 6.677 lebih besar (>) dari $\mathrm{T}$ tabel 1.761 dan nilai signifikansi 0,001 lebih kecil $(<)$ dari Nilai Probabilitas 0.05 dan Nilai t hitung variabel X2 (Pendidikan) 4.199 lebih besar (>) dari $\mathrm{T}$ tabel 1.761 dan nilai signifikansi 0,006 lebih kecil $(<)$ dari Nilai probabilitas 0.05 . Sehingga ketika Terjadi Perubahan pada nilai fluktuasi tingkat Pendidikan dan tingkat Kesehatan Naik atau turun secara signifikan mempengaruhi tingkat Pertumbuhan Ekonomi Di Kabupaten Teluk Bintuni. Keakuratan Variabel Dependen (X1, X2) mampu menjelaskan Vaiabel Independen (Y) sebesar $99,3 \%$ sedang sedang $7 \%$ dijelaskan oleh variabel lain yang tidak diukur dalam penelitian ini dan tertuang dalam Error term (standard erorr) yaitu Pengeluaran Rumah Tangga.

\section{DAFTAR PUSTAKA}

Dewi, N.L.S. and Sutrisna, I.K., 2014. Pengaruh Komponen Indeks Pembangunan Manusia Terhadap Pertumbuhan Ekonomi Provinsi Bali. E-Jurnal Ekonomi Pembangunan Universitas Udayana, 3(3), p.44443.
Dumairy. 1996. Perekonomian Indonesia. Jakarta: Erlangga.

Muda, R., Koleangan, R.A. and Kalangi, J.B., 2019. Pengaruh Angka Harapan Hidup, Tingkat Pendidikan dan Pengeluaran Perkapita Terhadap Pertumbuhan Ekonomi di Sulawesi Utara Pada Tahun 2003-2017. Jurnal Berkala Ilmiah Efisiensi, 19(01).

Nurhadi. 2012. Konsep Perwilayahan Dan Teori Pembangunan Dalam Geografi. Jurnal Ekonomi Pembangunan, 10(1), 49-66.

Priraharjo, K. 2007. Masalah Pendidikan di Indonesia. http://sayapbarat.wordpress .com/2007/08/29/masalah-pendidikandi-indonesia.

Sugiyono. 2012. Metode Penelitian Bisnis. Alfabeta, Bandung.

Sukirno, S. 2000. Makro ekonomi Modern: Perkembangan Pemikiran Dari Klasik Hingga Keynesian Baru. PT Raja Grafindo Pustaka. Jakarta

Sukirno, Sadono, 2008. Mikroekonomi: Teori Pengantar. Edisi Ketiga. Jakarta: PT Raja Grafindo Persada.

Todaro, M.P. dan Smith S.C. 2006. Pembangunan Ekonomi. Jakarta: Erlangga

Todaro, Michael P. 2011. Pembangunan Ekonomi Dunia Ketiga. Jakarta: Erlangga.

Wanga, S., Fua, B., Chen, H., \& Liu, Y. (2018). Regional development boundary of China's Loess Plateau: Water limit and land shortage. Land Use Policy, 74, 130-136. doi: https://doi.org/10.1016/j. landusepol.2017.03.003. 